\title{
Experimental evaluation of stable isotope fractionation in fish muscle and otoliths
}

\author{
T. S. Elsdon ${ }^{1,2, *}$, S. Ayvazian ${ }^{3}$, K. W. McMahon ${ }^{4}$, S. R. Thorrold ${ }^{2}$ \\ ${ }^{1}$ Southern Seas Ecology Laboratories, School of Earth and Environmental Sciences, Darling Building DX 650418 , \\ The University of Adelaide, Adelaide, South Australia 5005, Australia \\ ${ }^{2}$ Woods Hole Oceanographic Institution, Woods Hole, Massachusetts 02543, USA \\ ${ }^{3}$ Atlantic Ecology Division, US Environmental Protection Agency, Narragansett, Rhode Island 02882, USA \\ ${ }^{4}$ Massachusetts Institute of Technology and Woods Hole Oceanographic Institution, Joint Program in Oceanography and \\ Ocean Engineering, Woods Hole Oceanographic Institution, Woods Hole, Massachusetts 02543, USA
}

\begin{abstract}
Stable isotope analyses (SIA) of carbon and nitrogen are used routinely in food-web studies to determine diet and trophic position. We tested several common assumptions of SIA by rearing juvenile mummichog Fundulus heteroclitus on 5 isotopically distinct diets under controlled laboratory conditions. We determined the effect of diet type and lipid extraction on $\delta^{13} \mathrm{C}$ and $\delta^{15} \mathrm{~N}$ fractionation between diet and muscle. We also examined fractionation of $\delta^{13} \mathrm{C}$ between otolith and both diet and muscle. Both ${ }^{13} \mathrm{C}$ and ${ }^{15} \mathrm{~N}$ were enriched from diet to fish muscle, but the degree of fractionation differed among diets. Carbon isotope fractionation from diet to fish muscle exceeded assumed values of $<1 \%$ and ranged from 1.2 to $3.9 \%$, while nitrogen fractionation ranged from 2.7 to $7.8 \%$. Extracting lipids from fish muscle increased both $\delta^{13} \mathrm{C}$ and $\delta^{15} \mathrm{~N}$ by approximately $1 \%$. Lipid extraction also increased variation in treatment means for $\delta^{15} \mathrm{~N}$, but not $\delta^{13} \mathrm{C}$. Otoliths were enriched in ${ }^{13} \mathrm{C}$ compared to both diet and fish muscle. Bulk otolith $\delta^{13} \mathrm{C}$ values were strongly correlated with muscle tissue, and reflected the same total change in $\delta^{13} \mathrm{C}$ observed among diet treatments. It was tempting to conclude that otoliths were accurately recording $\delta^{13} \mathrm{C}$ values of the diet. However, more information is required on the effects of diet, metabolic rate, and $\delta^{13} \mathrm{C}$ of ambient dissolved inorganic carbon on otolith $\delta^{13} \mathrm{C}$ before these structures can be used to reconstruct diet histories of individual fish.
\end{abstract}

KEY WORDS: Diet $\cdot$ Food web $\cdot \delta^{13} \mathrm{C} \cdot \delta^{15} \mathrm{~N} \cdot$ Carbonate $\cdot$ Calcified structures $\cdot$ Isotope enrichment

\section{INTRODUCTION}

Understanding food webs and dietary history is vital in ecology, and underpins studies of behaviour, predation, trophic positioning, and competition (Hansson et al. 1997, Melville \& Connolly 2003, Estrada et al. 2005, Newsome et al. 2007). Traditional methods for determining diets involve stomach contents analysis, which provides a dietary snapshot on the time scale of days (Mann \& Orr 1969). However, stomach contents analysis can be difficult to interpret given the variability associated with rates of digestion and decomposition (Gannon 1976). Stable isotopes provide integrated esti- mates of diet over time that can be used to infer longerterm feeding behaviour and movements (Hobson \& Wassenaar 1999, Herzka \& Holt 2000, Haas et al. 2009). Carbon and nitrogen isotopes are primarily used for such interpretations as they provide information on diet and trophic positioning, respectively. Food-web reconstructions based on carbon and nitrogen isotopes rely upon prior knowledge of the isotopic fractionation between prey and consumers (Hobson \& Wassenaar 1999, Fry 2006). This fractionation is either measured or, more commonly, taken from the literature. Carbon isotopes are generally assumed to fractionate $<1 \%$ between prey and consumers, and nitrogen isotopes 
are assumed to fractionate approximately 3.5\% with trophic levels (Fry \& Sherr 1984, Minagawa \& Wada 1984, Vander Zanden \& Rasmussen 2001, Vanderklift \& Ponsard 2003, Fry 2006). These fractionation constants are then used to parameterise mixing models that aim to identify prey species consumed and the trophic level at which an individual feeds (Post 2002).

While carbon and nitrogen stable isotopes are commonly used in food-web studies, a number of issues with the technique remain unresolved. For instance, lipids are typically 6 to $8 \%$ depleted in ${ }^{13} \mathrm{C}$ relative to carbohydrates and proteins (DeNiro \& Epstein 1977). Systematic variation in consumer lipid content between sexes, with maturation, or on seasonal time scales may confound comparisons of $\delta^{13} \mathrm{C}$ values within the same species (McConnaughey \& McRoy 1979, Focken \& Becker 1998). Interpretation of dietary items is difficult when variation in $\delta^{13} \mathrm{C}$ caused by differences in lipid content is larger than the assumed fractionation between diet and consumers $(<1 \%$ ). The removal of lipids from tissue samples is, therefore, a logical way to reduce error associated with stable isotope analyses (SIA) (Pinnegar \& Polunin 1999, Murry et al. 2006). Two methods currently exist to correct for differences in lipid content among consumers: extracting lipids from samples (e.g. Sotiropoulos et al. 2004) or mathematically correcting data (Kiljunen et al. 2006, Sweeting et al. 2006). It is not clear, however, under which scenarios either technique is able to successfully correct for variable lipid content in field samples (Post et al. 2007).

Lipid removal effects on $\delta^{15} \mathrm{~N}$ values are less well understood than for $\delta^{13} \mathrm{C}$ values. Most lipids do not contain nitrogen and, in theory, lipid extraction should have little influence on $\delta^{15} \mathrm{~N}$ measurements in bulk tissue. If lipid extraction removes metabolic waste then tissue samples should have lipids removed (Bearhop et al. 2000, Sotiropoulos et al. 2004). If however, lipid extraction strips nitrogen atoms from protein, then removing lipids may either bias or add unnecessary variation to the assay (Murry et al. 2006). There is little consensus on this question in the literature, with some researchers extracting lipids before $\delta^{15} \mathrm{~N}$ analysis (e.g. Post 2002, Gaye-Siessegger et al. 2004, Schlechtriem et al. 2004, Logan \& Lutcavage 2008) and others not extracting their samples (e.g. Hansson et al. 1997, Goedkoop et al. 2006). Clearly we need a more mechanistic understanding of sample treatment effects on $\delta^{15} \mathrm{~N}$ values when using SIA in food-web studies.

A further issue complicating the interpretation of stable isotopes occurs when consumer tissues fail to track dietary items due to isotopic routing (Schwarcz 1991). The carbon skeletons of different dietary constituents (e.g. proteins, lipids, and carbohydrates) can be routed to different consumer tissue constituents. Typically, bulk trophic fractionation between diet and consumer assumes a constant degree of de novo synthesis of tissue constituents. However, diet $\delta^{13} \mathrm{C}$ values and those of the consumer may be decoupled if the degree to which lipids or amino acids are routed directly into tissue versus synthesized de novo varies due to diet or physiological conditions (K. E. McMahon et al. unpubl. data). Few studies have emphasized the problems that isotopic routing poses to the interpretation of isotopic data in diet reconstructions (e.g. Parkington 1991, Schwarcz 1991).

Fish otoliths are comprised of calcium carbonate $\left(\mathrm{CaCO}_{3}\right)$ and contain substantial carbon that may be useful for isotopic investigations of diet. One advantage of otoliths over other tissues for dietary analyses is that otoliths accrete new material onto their outside edge daily that is metabolically inert once incorporated. Unlike muscle, which has a fairly rapid turnover rate, the isotopic composition of individual growth increments in otoliths may record dietary information on fine temporal scales over the lifetime of an individual fish. Nitrogen is a minor constituent of otoliths, presumably located within the protein matrix (Campana 1999), and $\delta^{15} \mathrm{~N}$ analysis of bulk otolith material is difficult. Carbon in otoliths comes from dietary sources via metabolism and from dissolved inorganic carbon (DIC) (Kalish 1991, Radtke et al. 1996, Solomon et al. 2006). Metabolic carbon contributes approximately 25\% to total otolith carbon (Høie et al. 2003), but published values range between $0 \%$ (Kalish 1991) and 100\% (Wurster \& Patterson 2003). The mechanisms generating such variability in the contribution of metabolic carbon to otoliths are not understood.

The aim of the present study was to examine factors controlling trophic fractionation of carbon and nitrogen stable isotopes in fish muscle and otoliths. Our specific objectives were to (1) determine the degree of fractionation of $\delta^{13} \mathrm{C}$ and $\delta^{15} \mathrm{~N}$ between diet and muscle, and assess if fractionation was consistent among fish feeding on different diets, (2) test the effect of extracting lipids from fish muscle on fractionation, and (3) examine the consistency of fractionation of $\delta^{13} \mathrm{C}$ between otoliths and both diet and muscle among fish feeding on different diets, and determine the metabolic contribution of carbon to otoliths. These 3 objectives were addressed under controlled lab conditions to minimise the potential effects of systematic genetic or environmental differences among diet treatments.

\section{MATERIALS AND METHODS}

Fish rearing. Adult mummichog Fundulus heteroclitus, Linnaeus 1766 were collected from a saltmarsh in Sandwich, Massachusetts, and transported to the Atlantic Ecology Division, US Environmental Protec- 
tion Agency (USEPA), in Narragansett, Rhode Island. Fish were held in flow-through seawater with temperatures elevated above ambient to induce spawning. Mummichog spawn on the full moon (Collette \& KleinMacPhee 2002) during spring through summer (May to July) and females deposit eggs on substrate, or surrogate collecting baskets in the laboratory. Eggs from 2 spawning events, 28 May and 19 June 2006, were collected and transferred to tanks and allowed to hatch. Juvenile fish were reared in tanks for $6 \mathrm{wk}$ (approximate length of $11 \mathrm{~mm}$ ) and fed only on Artemia from the time of hatching. After 6 wk they were transferred to experimental tanks.

Experimental tanks consisted of fifteen 401 aquariums with flow-through seawater at a temperature of $20^{\circ} \mathrm{C}$. Tanks were randomly positioned in 2 rows and light was administered under a $12 \mathrm{~h}$ light:12 h dark cycle from fluorescent tubes. Twenty fish were stocked into each tank. Before commencing any dietary manipulations, 30 fish were sacrificed to determine average otolith weight and isotopic values, which were then used in subsequent calculations. Dietary manipulations consisted of 3 tanks of fish that were fed 1 of 5 diets: (1) Artemia, (2) vegi-pro®, (3) bio-vita ${ }^{\circledR}$, (4) squid, or (5) clam. Diets were selected due to their different isotopic signatures. Vegi-pro is a commercial fish pellet made from vegetable-based protein, whereas bio-vita is a commercial fish pellet made from fish-based protein. Fish fed Artemia diets were considered control fish, as their dietary sources of carbon and nitrogen isotopes had not changed since hatching. Squid and clam diets were made by homogenising $500 \mathrm{~g}$ of each and freezing in small amounts. Fish were fed to saturation once per day, and tanks were cleaned of excess food and biofilms every third day. Fish were reared on different dietary treatments for $8 \mathrm{wk}$, after which they were sacrificed in an ice slurry and frozen.

Sample preparation. Muscle and diet: Fish were stored frozen then freeze-dried whole for $72 \mathrm{~h}$ ( $\mathrm{n}=5$ fish per tank). White muscle samples were collected and homogenised for each individual fish using a mortar and pestle, before being split into 2 portions for analyses. One portion was analysed for $\delta^{13} \mathrm{C}$ and $\delta^{15} \mathrm{~N}$, and the other had lipids extracted prior to isotopic analysis. Lipid-extracted samples were analysed for both $\delta^{13} \mathrm{C}$ and $\delta^{15} \mathrm{~N}$.

Approximately $1 \mathrm{mg}$ of sample was weighed into tin cups and analysed for $\delta^{13} \mathrm{C}$ and $\delta^{15} \mathrm{~N}$ values using a Europa Hydra 20/20 isotope ratio monitoring mass spectrometer (irm-MS) at the UC Davis Stable Isotope Facility. The second portion of sample had lipids extracted by triple washing $1 \mathrm{mg}$ of muscle with dichloromethane-methanol (DCM:MEOH, 1:1) and pipetting off the solvent (Murry et al. 2006). After the third wash, the remaining solvent was evaporated under inert $\mathrm{N}_{2}$ gas at $50^{\circ} \mathrm{C}$. Approximately $1 \mathrm{mg}$ of lipid extracted muscle was weighed into tin cups and analysed for $\delta^{13} \mathrm{C}$ and $\delta^{15} \mathrm{~N}$ composition as previously described. Stable isotopes were expressed in standard delta $(\delta)$ notation as parts per thousand $(\%)$ :

$$
\delta^{13} \mathrm{C} \text { or } \delta^{15} \mathrm{~N}=\left(\frac{\left(R_{\text {sample }}-R_{\text {standard }}\right)}{R_{\text {standard }}}\right) \times 1000
$$

where $R$ is the ratio of ${ }^{13} \mathrm{C}:{ }^{12} \mathrm{C}$ or ${ }^{15} \mathrm{~N}:{ }^{14} \mathrm{~N}$. Results were reported relative to Vienna Pee Dee Belemnite (VPDB) for $\delta^{13} \mathrm{C}$ and atmospheric air for $\delta^{15} \mathrm{~N}$. Powder standards (NB519) were analysed to assess instrument drift and calculate precision.

Samples of diet consumed by fish (Artemia, vegi-pro, bio-vita, squid, and clam) were analysed for $\delta^{13} \mathrm{C}$ and $\delta^{15} \mathrm{~N}$ values $(\mathrm{n}=5)$, with these samples being a composite of the feeds over the experiment. Methods of analyses followed those described for muscle, with the exception that lipids were not extracted.

Otoliths: Otoliths of frozen fish were dissected prior to freeze drying. Otoliths were washed in ultrapure water to remove any remaining tissue then further cleaned with a triple rinse of ultrapure water before being freeze-dried and stored in microcentrifuge tubes. Five replicate fish from each tank were selected for the analysis of otolith $\delta^{13} \mathrm{C}$ using a irm-MS. Whole otoliths were analysed and mean $( \pm \mathrm{SE})$ sample mass was $298.2 \pm 8.4 \mathrm{mg}$ and corrected for previous growth on Artemia (see 'Data analyses' for a description of this correction). Sample preparation included weighing and placing otoliths in glass vials, adding $3 \%$ hydrogen peroxide and crushing otoliths using a glass probe, rinsing and drying at $50^{\circ} \mathrm{C}$ before analysis. Samples were analysed on a Thermo Finnigan Mat 253 irm-MS with a Kiell III carbonate device following the methods of Ostermann \& Curry (2000). Isotope values were reported relative to $\mathrm{VPDB}$, and expressed in standard delta $(\delta)$ notation as parts per thousand $(\%)$ :

$$
\delta^{13} \mathrm{C}=\left(\frac{R_{\text {sample }}}{R_{\text {standard }}}-1\right) \times 1000
$$

where $R$ is the ratio of ${ }^{13} \mathrm{C}:{ }^{12} \mathrm{C}$. Powder standards (NBS19 and bicarbonate) were analysed to assess instrument drift and calculate precision; long-term precision estimates of the mass spectrometer were $\delta^{13} \mathrm{C} \pm 0.03$ (Ostermann \& Curry 2000).

Data analyses. Estimates of $\delta^{13} \mathrm{C}$ in whole otoliths for each diet treatment also incorporated otolith material deposited when all fish were fed Artemia ( 0 to 6 wk of age). We therefore used the following equation to correct for otolith material deposited before the diet switch:

$$
\begin{aligned}
& \left(\mathrm{OW}_{\text {whole }} \times \delta^{13} \mathrm{C}_{\text {whole }}\right)- \\
& \delta^{13} \mathrm{C}_{\text {final }}=\frac{\left(\text { mean } O W_{\text {initial }} \times \text { mean } \delta^{13} \mathrm{C}_{\text {initial }}\right)}{\left(\mathrm{OW}_{\text {whole }}-\text { mean } \mathrm{OW}_{\text {initial }}\right)}
\end{aligned}
$$


where OW is otolith weight; $\mathrm{OW}_{\text {whole }}$ and $\delta^{13} \mathrm{C}_{\text {whole }}$ represent values of an individual fish at the end of the experiment and mean $\mathrm{OW}_{\text {initial }}$ and mean $\delta^{13} \mathrm{C}_{\text {initial }}$ represent average values based on the 30 fish sampled after $6 \mathrm{wk}$.

Isotopic composition of fish muscle was determined for untreated and lipid-extracted samples. Lipid extraction required additional sample processing that may increase within-treatment variation. Therefore, we compared the variation associated with each method (untreated and lipid-extracted) by calculating variation estimates (SD) for each tank within each diet treatment. We then compared treatments between untreated and lipid-extracted samples using ANOVA. To determine if the method of analysis altered the interpretation of the data, we compared statistical significance and estimates of variation associated with each method. We used ANOVA and permutational multivariate ANOVA (PERMANOVA) to determine if diet treatments differed, and variance components (Vaughan \& Corballis 1969, Graham \& Edwards 2001) to estimate the magnitude of effect explained by differences among diets.

Differences in isotopic composition $\left(\delta^{13} \mathrm{C}\right.$ and $\left.\delta^{15} \mathrm{~N}\right)$ of food and fish muscle were compared among treatments using a PERMANOVA in PRIMER-E (see Anderson 2001, McArdle \& Anderson 2001 for further details), where rows of data are permuted randomly among groups, and an F-statistic calculated. Euclidean distances were used. Where significant differences were detected, we used pair-wise a posteriori comparisons to determine which treatments differed. Univariate ANOVAs were used to determine differences among treatments of single variables $\left(\delta^{13} \mathrm{C}, \delta^{15} \mathrm{~N}, \mathrm{C}: \mathrm{N}\right)$ and isotope enrichments for diet, fish muscle, and otoliths, and to determine if fish growth (length and weight) differed among treatments over the duration of the experiment.

\section{RESULTS}

Diets fed to fish differed in their $\delta^{13} \mathrm{C}$ and $\delta^{15} \mathrm{~N}$ values (PERMANOVA: $F_{4,20}=1309.76, \mathrm{p}=0.002$ ), with all diets varying significantly from one another. The vegipro diet had an isotopic composition that was very different from all other diets, with significantly lower $\delta^{13} \mathrm{C}$ and $\delta^{15} \mathrm{~N}$ values (Fig. 1). Diets of bio-vita, Artemia, and clam had relatively similar $\delta^{15} \mathrm{~N}$ values but different $\delta^{13} \mathrm{C}$ values, while squid had the highest $\delta^{15} \mathrm{~N}$ value. The carbon:nitrogen ratio ( $\mathrm{C}: \mathrm{N})$ differed among diets (ANOVA: $F_{4,20}=715.84, \mathrm{p}=0.0000$ ), and diets of vegipro and bio-vita had higher C:N (mean $=5.55$ and 5.65, respectively) than Artemia (3.95), squid (3.58), and clam (3.55; pairwise comparisons: vegi-pro = bio-vita > Artemia $>$ squid $=$ clam $)$.

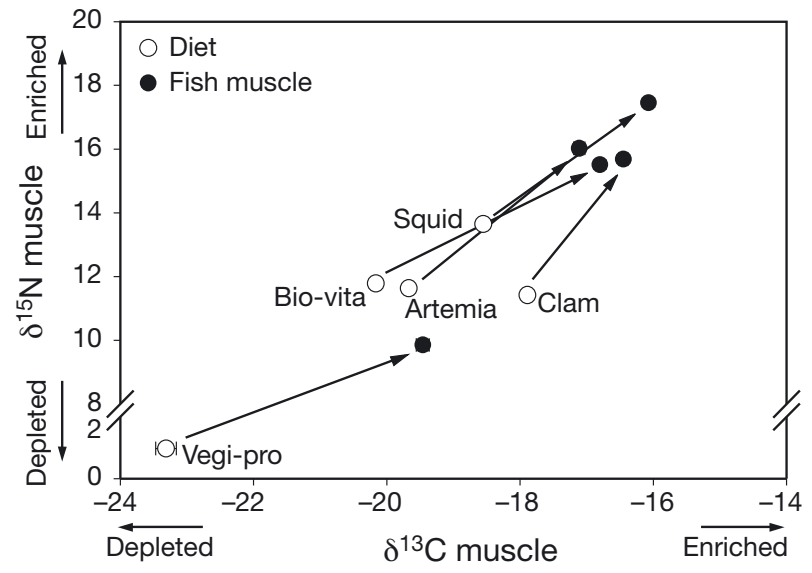

Fig. 1. Isotopic enrichment of $\delta^{13} \mathrm{C}$ and $\delta^{15} \mathrm{~N}$ from dietary components to mummichog Fundulus heteroclitus muscle. Arrows indicate change between diet and fish muscle treatments. Data are means $\pm \mathrm{SE}$

Fish length and weight were not significantly different among diet treatment groups (length: $F_{4,10}=2.88$, $\mathrm{p}=0.0794$; weight: $F_{4,10}=2.76, \mathrm{p}=0.0877$ ), indicating that growth and, therefore, tissue turnover was not affected by diet treatment. Growth of fish in all diet treatments after $8 \mathrm{wk}$ of rearing was, however, substantially greater than an initial subsampled group of fish (length: $F_{1,10}=207.425, \mathrm{p}=0.0002$; weight: $F_{1,102}=$ $170.22, \mathrm{p}=0.0001$ ). During the experiment, fish increased in length by $153 \%$ and weight by $129 \%$.

Fish reared on vegi-pro, bio-vita, squid, or clam for 8 wk after an initial diet of Artemia had unique isotopic values (both $\delta^{13} \mathrm{C}$ and $\delta^{15} \mathrm{~N}$ ) within their muscle ('Diet' effects all significant; Table 1a). All treatments differed significantly from one another based on pairwise comparisons, and from fish fed only Artemia (Fig. 2). For $\delta^{13} \mathrm{C}$, differences among diets represented $96.39 \%$ of total variation for untreated samples and $95.64 \%$ of variation for lipid-extracted samples (Table 1a). Similar differences among diets were detected for $\delta^{15} \mathrm{~N}$ and the multivariate signature of $\delta^{13} \mathrm{C}(99.29 \%$ untreated, $96.33 \%$ lipid-extracted) and $\delta^{15} \mathrm{~N}(98.81 \%$ untreated, $94.69 \%$ lipid-extracted; Table 1a). The relationship between dietary $\delta^{13} \mathrm{C}$ and $\delta^{15} \mathrm{~N}$ in diets and muscle was confirmed by strong positive correlations between diet and muscle isotope composition for both $\delta^{13} \mathrm{C}$ and $\delta^{15} \mathrm{~N}$ isotopes (Fig. 2). Fish reared on different diets had similar muscle C:N values (ANOVA: $F_{4,10}=0.20, p=$ $0.9341)$, which ranged from a mean $( \pm \mathrm{SE})$ of $3.32 \pm 0.04$ for the clam diet to $3.37 \pm 0.06$ for vegi-pro.

\section{Fractionation from diet to fish muscle}

Fractionation between diet and fish muscle occurred for both $\delta^{13} \mathrm{C}$ and $\delta^{15} \mathrm{~N}$. Isotopic fractionation between 
Table 1. (a) ANOVAs and PERMANOVAs comparing lipid-extracted and untreated $\delta^{13} \mathrm{C}$ and $\delta^{15} \mathrm{~N}$ among diet treatments. VC\%: variance component calculations (see 'Materials and methods'). (b) ANOVA comparing differences in $\delta^{13} \mathrm{C}$ and $\delta^{15} \mathrm{~N}$ among methods (lipid-extracted versus untreated) and diet treatments, and (c) ANOVA comparing difference in variance among methods (lipid-extracted versus untreated) and diet treatments. Bold values indicate significant variance components

\begin{tabular}{|c|c|c|c|c|c|c|c|}
\hline \multirow[t]{2}{*}{ (a) Source of variation } & \multirow[t]{2}{*}{ df } & \multicolumn{3}{|c|}{ Lipid-extracted } & \multirow{2}{*}{ MS } & \multirow{2}{*}{$\begin{array}{c}\text { Untreated } \\
\mathrm{p}\end{array}$} & \multirow[b]{2}{*}{$\mathrm{VC}(\%)$} \\
\hline & & MS & $\mathrm{p}$ & $\mathrm{VC}(\%)$ & & & \\
\hline \multicolumn{8}{|l|}{$\delta^{13} \mathrm{C}$} \\
\hline Diet & 4 & 24.5753 & 0.0000 & 96.39 & 26.6681 & 0.0000 & 95.64 \\
\hline Tank (Diet) & 10 & 0.1291 & 0.0047 & 1.01 & 0.0363 & 0.9155 & $0.00^{\mathrm{b}}$ \\
\hline Error & 60 & 0.0440 & & 2.60 & 0.0809 & & 4.36 \\
\hline \multicolumn{8}{|l|}{$\delta^{15} \mathrm{~N}$} \\
\hline Diet & 4 & 128.0114 & 0.0000 & 99.29 & 128.4788 & 0.0000 & 96.33 \\
\hline Tank (Diet) & 10 & 0.1142 & 0.0185 & 0.15 & 0.0980 & 0.9783 & $0.00^{\mathrm{b}}$ \\
\hline Error & 60 & 0.0478 & & 0.56 & 0.3260 & & 3.67 \\
\hline \multicolumn{8}{|c|}{ Multivariate $\left(\delta^{13} \mathrm{C} \& \delta^{15} \mathrm{~N}\right)$} \\
\hline Diet & 4 & 152.59 & 0.0002 & 98.81 & 154.1725 & 0.0002 & 94.69 \\
\hline Tank (Diet) & 10 & 0.2433 & 0.0100 & 0.30 & 0.2087 & 0.9594 & $0.00^{\mathrm{b}}$ \\
\hline Error & 60 & 0.0918 & & 0.89 & 0.5754 & & 6.31 \\
\hline \multirow[t]{2}{*}{ (b) Source of variation } & \multirow[t]{2}{*}{ df } & \multicolumn{2}{|c|}{ Carbon } & & \multicolumn{2}{|c|}{- Nitrogen -} & \\
\hline & & MS & $\mathrm{p}$ & & MS & $\mathrm{p}$ & \\
\hline Method & 1 & 137.5901 & 0.0000 & & 40.8204 & 0.0000 & \\
\hline Diet & 4 & 51.0887 & 0.0000 & & 256.4107 & 0.0000 & \\
\hline Tank (Method × Diet) & 20 & 0.0827 & 0.1769 & & 0.1061 & 0.9278 & \\
\hline Method $\times$ Diet & 4 & 0.1547 & 0.1551 & & 0.0795 & 0.5701 & \\
\hline Error & 120 & 0.0624 & & & 0.1869 & & \\
\hline \multirow[t]{2}{*}{ (c) Source of variation } & \multirow[t]{2}{*}{ df } & \multicolumn{2}{|c|}{ Carbon $^{\mathrm{a}}$} & & \multicolumn{2}{|c|}{$\longrightarrow$ Nitrogen -} & \\
\hline & & MS & $\mathrm{p}$ & & MS & $\mathrm{p}$ & \\
\hline Method & 1 & 0.0112 & 0.2575 & & 0.9901 & 0.0000 & \\
\hline Diet & 4 & 0.0348 & 0.0122 & & 0.0650 & 0.0112 & \\
\hline Method $\times$ Diet & 4 & 0.0023 & 0.8902 & & 0.0092 & 0.6578 & \\
\hline Error & 20 & 0.0082 & & & 0.0151 & & \\
\hline \multicolumn{8}{|l|}{${ }^{\mathrm{a}} \operatorname{Ln}(x+1)$-transformed } \\
\hline${ }^{b}$ Negative estimate of & dju & & & & & & \\
\hline
\end{tabular}

diet and muscle was not consistent among fish fed different diets (see significant ANOVA; Table 2, Fig. 2). Please note that we used a combination of lipidextracted $\delta^{13} \mathrm{C}$ and untreated $\delta^{15} \mathrm{~N}$ values in subsequent analyses (see 'Effects of lipid extraction' in 'Results' for explanation). For $\delta^{13} \mathrm{C}$ (lipid-extracted), tissues were enriched by values ranging from $1.24 \%$ for clam to $3.85 \%$ o for vegi-pro relative to diet (Table 2, Fig. 2). The highest levels of $\delta^{13} \mathrm{C}$ enrichment occurred with the artificial diets of vegi-pro and bio-vita, suggesting selective incorporation of ${ }^{13} \mathrm{C}$ (Table 2, Fig. 2). For $\delta^{15} \mathrm{~N}$, enrichment from diet to untreated fish muscle ranged from $2.66 \%$ o for squid to $7.83 \%$ for vegi-pro (Table 2). A combination of large $\delta^{13} \mathrm{C}$ enrichment in bio-vita and $\delta^{15} \mathrm{~N}$ enrichment in Artemia caused a switch in the position of these treatments relative to their position in the diet (see significant ANOVA; Table 2, Fig. 1).

\section{Effects of lipid extraction}

Lipid extraction caused a shift in the stable isotope ratios of treatments relative to untreated data based on both $\delta^{13} \mathrm{C}$ and $\delta^{15} \mathrm{~N}$ values (Table $1 \mathrm{~b}$ ); however, the relative placement of the treatment groups to each other remained similar (Fig. 3). Fish muscle that had lipids extracted was significantly enriched in both $\delta^{13} \mathrm{C}$ and $\delta^{15} \mathrm{~N}$ isotopes (Table 1b, Fig. 3). The difference between untreated and lipid-extracted muscle was on average (mean $\pm \mathrm{SE}$ ) $1.00 \pm 0.04 \%$ for $\delta^{13} \mathrm{C}$ and $1.04 \pm$ $0.07 \%$ for $\delta^{15} \mathrm{~N}$ (Fig. 3).

Lipid extraction increased variation in $\delta^{15} \mathrm{~N}$ values, but not in $\delta^{13} \mathrm{C}$ values (Table 1c, Fig. 3). For $\delta^{15} \mathrm{~N}$, the increased variation due to lipid extraction compared to untreated samples was seen in the significant 'Method' effect (Table 1c, Fig. 3). We also detected significant effects of diet treatments on variance for both $\delta^{13} \mathrm{C}$ and 

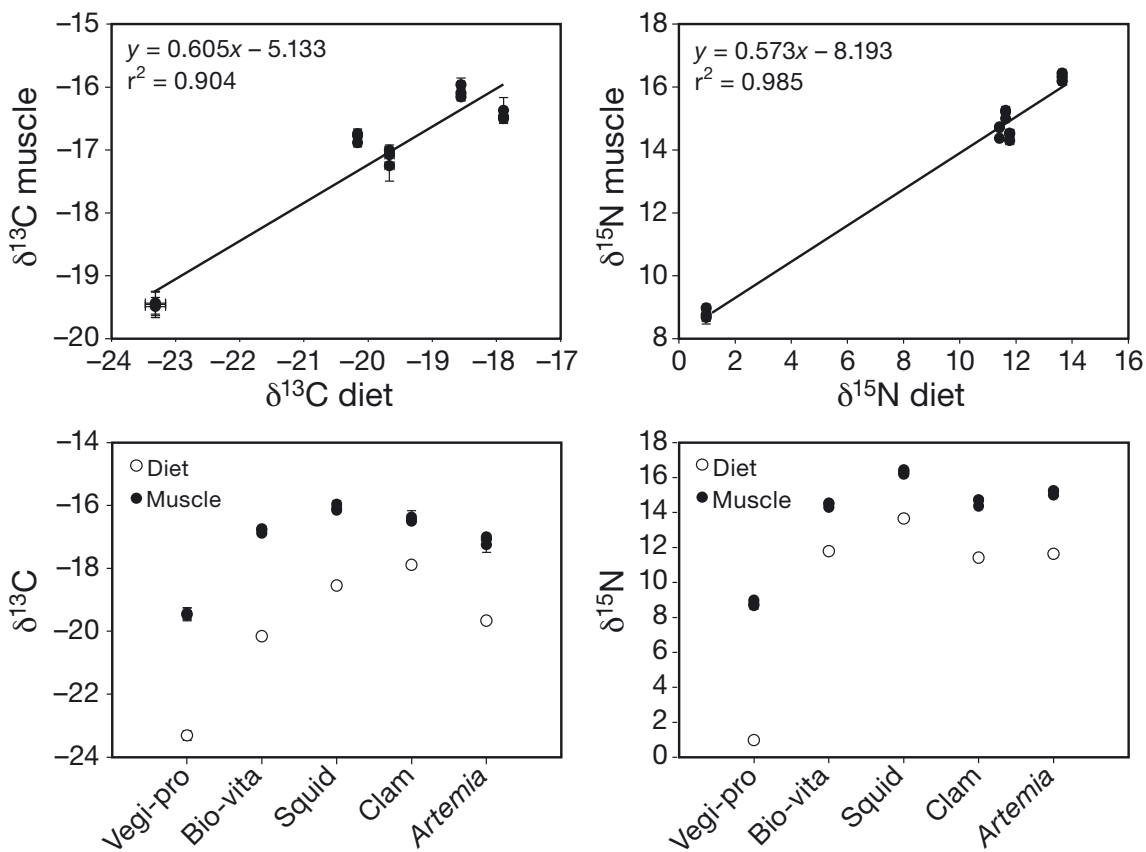

Fig. 2. Relationships between isotopes in mummichog Fundulus heteroclitus muscle $\left(\delta^{13} \mathrm{C}\right.$ and $\left.\delta^{15} \mathrm{~N}\right)$ and diet displayed as regressions. Fractionation between diet and fish muscle is shown for each dietary treatment (vegi-pro, bio-vita, squid, clam, and Artemia). Data are means \pm SE

$\delta^{15} \mathrm{~N}$ (Table 1c), which was caused by higher variation in vegi-pro diets compared to all other diets (StudentNewman-Keuls [SNK] tests; vegi-pro > all other diets, which were equal; Fig. 3).

\section{Fractionation from diet and muscle to otoliths}

The carbon isotope composition of fish otoliths reflected that of their diets $\left(\mathrm{r}^{2}=0.996\right.$; Fig. 4). Otolith $\delta^{13} \mathrm{C}$ values differed significantly among dietary treatments (ANOVA: $F_{4,10}=39.80, \mathrm{p}<$ 0.0001). The treatments of squid and clam had similar $\delta^{13} \mathrm{C}$ compositions that were in turn more enriched than biovita and Artemia, with vegi-pro being the least enriched (SNK tests: squid = clam $>$ bio-vita $=$ Artemia $>$ vegi-pro; Fig. 4). Isotope enrichment ranged from $12.1 \%$ for clam to $14.5 \%$ o for vegi-pro (Table 2), with the greatest $\delta^{13} \mathrm{C}$ enrichment detected in fish that were fed the artificial diet of vegi-pro.

Isotopic composition of otoliths reflected that of fish muscle, as indicated by a strong positive relationship between $\delta^{13} \mathrm{C}$ composition of fish muscle and that in otoliths $\left(\mathrm{r}^{2}=0.837\right.$; Fig. 4). Isotope enrichment of $\delta^{13} \mathrm{C}$ from fish muscle to otolith ranged from $9.66 \%$ for Artemia to $10.66 \%$ for clam, with enrichments being relatively consistent among treatments (Table 2). In general, fractionation between fish muscle and otolith was more consistent among treatments than fractionation between diet and otolith (i.e.

Table 2. (a) Isotopic enrichment from diet to fish muscle for both $\delta^{13} \mathrm{C}$ and $\delta^{15} \mathrm{~N}$ untreated and lipid-extracted data, and (b) isotopic enrichment from diet and muscle to fish otoliths $\left(\delta^{13} \mathrm{C}\right.$ only). ANOVA results are presented as F-ratios and significance levels to indicate whether diet treatments had significantly different isotopic enrichment. Data are means $\pm \mathrm{SE}, \mathrm{n}=15$ fish. $\mathrm{ns}$ : non-significant; ${ }^{*} \mathrm{p}<0.05 ;{ }^{* * *} \mathrm{p}<0.001$

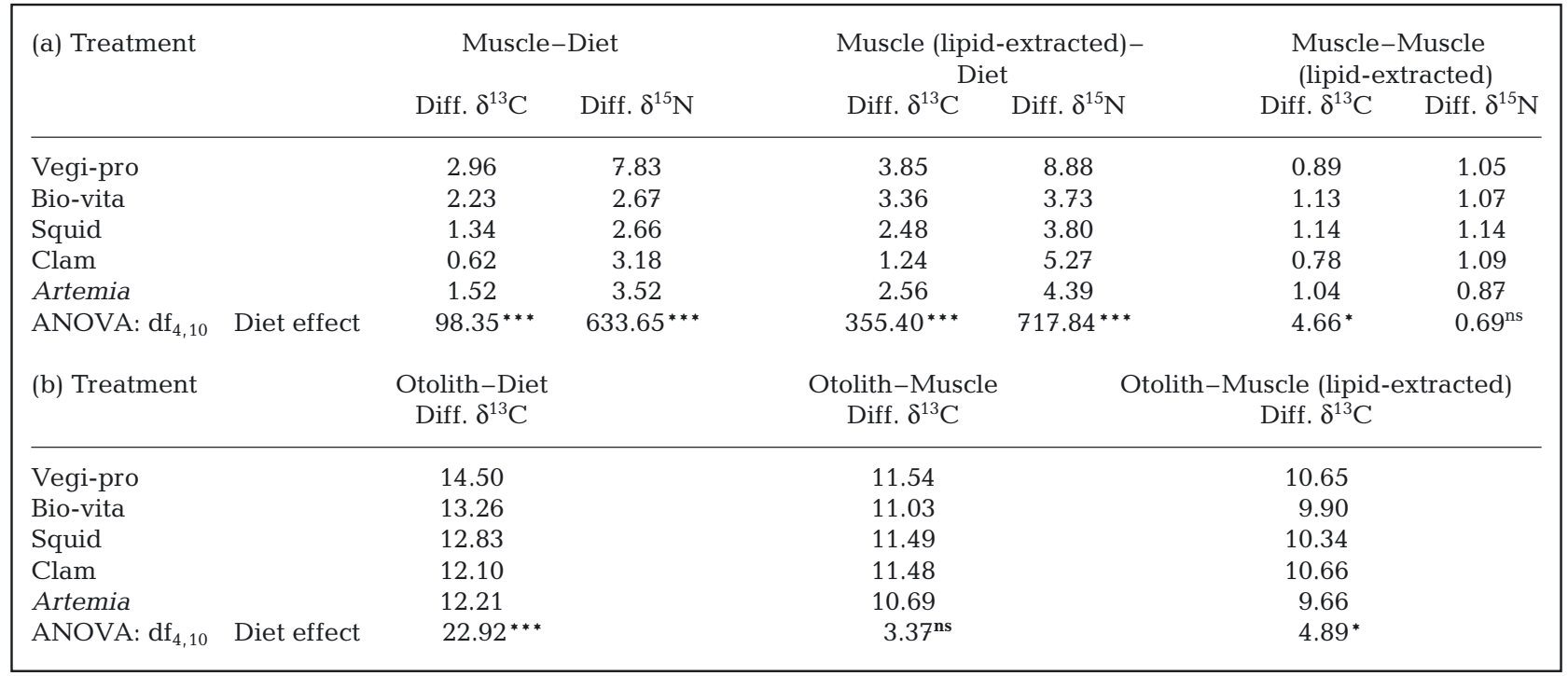



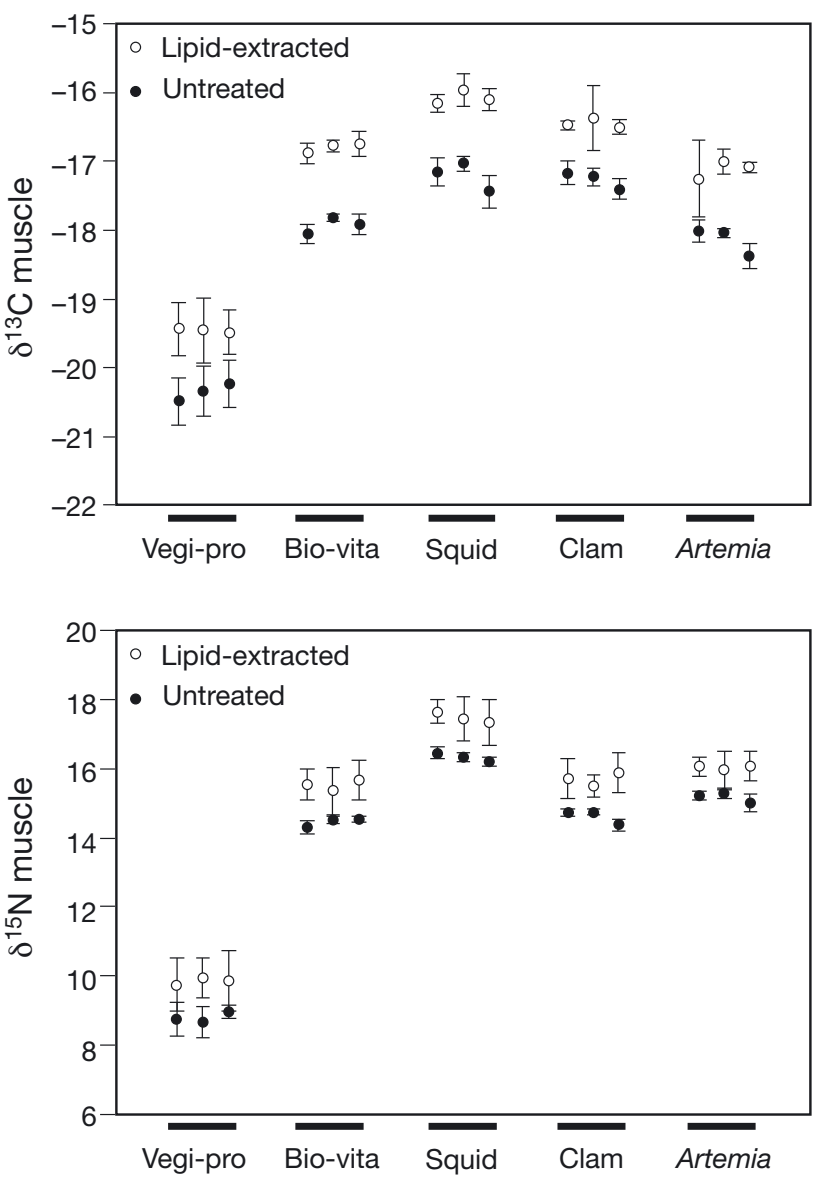

Fig. 3. Isotopic enrichment that occurs with lipid extraction of mummichog Fundulus heteroclitus muscle, displaying the variation structure for each tank for both untreated and lipidextracted samples. Data are means $\pm \mathrm{SE}$
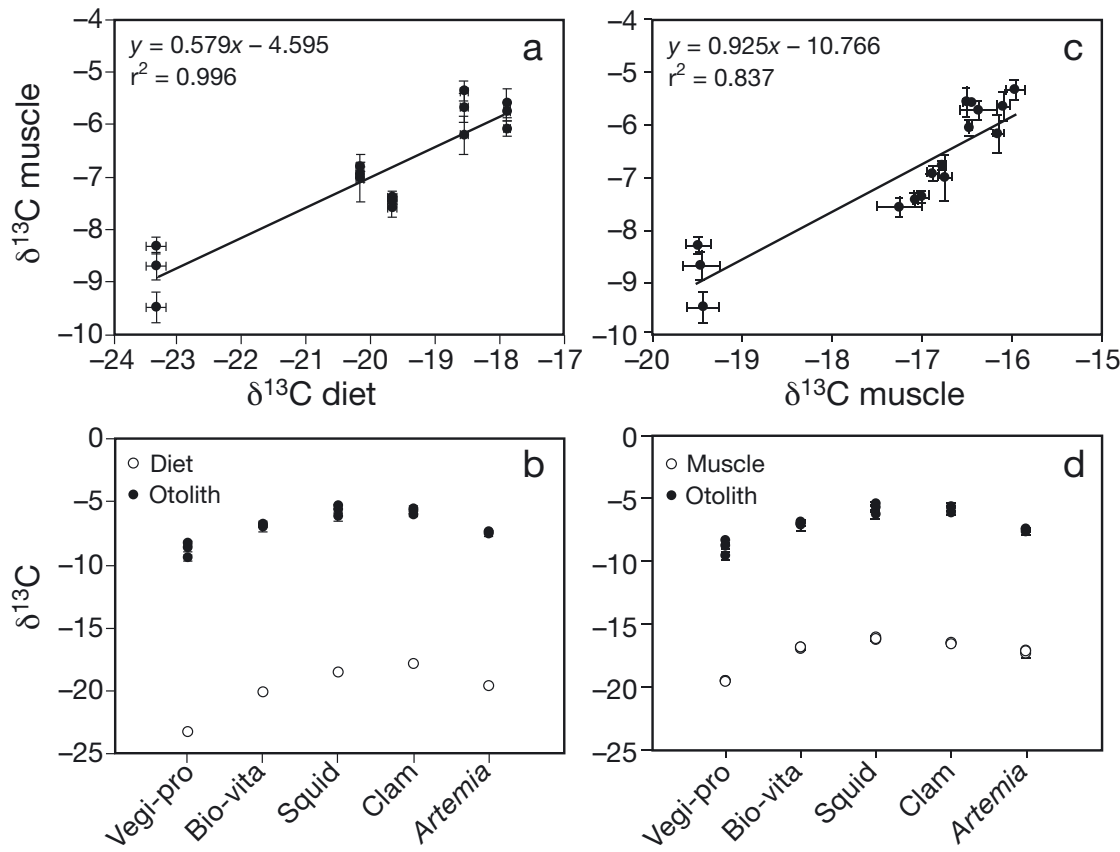

diet to otolith was significant, muscle to otolith was not, ANOVA; Table 2). Enrichments from diet to muscle were also considerably less $(\sim 3 \%)$ than those from muscle to otoliths ( $10 \%$, ANOVA; Table 2$)$. Finally, otolith $\delta^{13} \mathrm{C}$ values reflected the same total change in muscle tissue $\delta^{13} \mathrm{C}$ (Fig. 4).

\section{DISCUSSION}

SIA of carbon and nitrogen has become an important tool in food-web studies conducted in terrestrial and aquatic environments (Fry 2006). The approach overcomes many of the biases that may be encountered using traditional stomach contents analysis that often provide only a snapshot of relatively indigestible food items. However, questions still remain concerning some of the fundamental assumptions of SIA and the appropriate analytical techniques to be used. Many of these questions are best resolved using controlled laboratory studies where different diets can be unambiguously assigned to individual fish. Taking such an approach, we found that at least some of the common assumptions about fractionation constants of $1 \%$ o for $\delta^{13} \mathrm{C}$ and 3 to $4 \%$ per trophic level for $\delta^{15} \mathrm{~N}$ used in SIA are unlikely to be met in field studies and deserve more attention from the researchers using this technique.

The results of the present study rest on the assumption that muscle tissue of the juvenile mummichog had reached isotopic equilibrium by the end of the experiment. Several lines of evidence suggest that this assumption was met. Previous research suggested that carbon and nitrogen turnover in mummichogs was rapid, with muscle tissues being close to isotopic equilibrium after approximately $50 \mathrm{~d}$ based on mass increase, and complete equilibrium reached at $104 \mathrm{~d}$ (Logan et al. 2008). We reared fish for $56 \mathrm{~d}$ after swapping diets within the laboratory and during this time fish increased their length and mass significantly, indicating growth and that metabolic tissue growth and

Fig. 4. Relationships between isotopes in mummichog Fundulus heteroclitus otoliths $\left(\delta^{13} \mathrm{C}\right)$ and (a) diet and (c) muscle displayed as regressions. Fractionation between otolith and (b) diet and (d) muscle shown for each dietary treatment (vegi-pro, bio-vita, squid, clam, and Artemia). Data are means \pm SE 
turnover did occur. Growth was also consistent among fish fed different diets, suggesting that fish growth was not impaired in any of the diet treatments. Finally, and most persuasively, we assayed $\delta^{13} \mathrm{C}$ values in individual amino acids (AA) from the same fish used in the present study (K. E. McMahon et al. unpubl. data). Most animals have lost the ability to synthesize essential AAs de novo and therefore must incorporate them directly from their diet. We found that $\delta^{13} \mathrm{C}$ values in 5 essential AAs were indistinguishable from those in the individual diets at the end of the experiment, indicating that isotopic equilibrium had been achieved in muscle tissue by the end of the experiment. Taken together, it appears unlikely that our data were compromised by a failure of the juvenile fish to reach isotopic equilibrium in any of the diet treatments.

\section{Fractionation from diet to fish muscle and consistencies of trends}

The use of stable carbon and nitrogen isotopes in dietary and trophic investigations is based on the assumptions that $\delta^{13} \mathrm{C}$ and $\delta^{15} \mathrm{~N}$ fractionation is known, and that carbon and nitrogen move through the food web with similar stoichiometry (Post 2002, Fry 2006). The fractionation we detected was relatively large compared to that described in most, but not all, previous studies. The diets in our feeding experiment had different $\delta^{13} \mathrm{C}$ values, as was expected based upon their composition. Vegi-pro had the lowest $\delta^{13} \mathrm{C}$ value $(-23.3 \pm 0.4 \%)$ reflecting its composition of wheat $\left(\mathrm{C}_{3}\right.$ plant $\delta^{13} \mathrm{C} \delta-27 \%$ ) and a relatively small contribution of corn $\left(\mathrm{C}_{4}\right.$ plant $\left.\delta^{13} \mathrm{C} \delta-12 \%\right)$. The natural diets of squid and clam had the highest $\delta^{13} \mathrm{C}$ values, reflecting a marine origin (Chisholm et al. 1982). Bio-vita was intermediate between vegi-pro and the natural diets, reflecting the presence of fish and krill meal as well as wheat gluten and whey protein. Fish exhibited fractionation between diets and muscle $\delta^{13} \mathrm{C}$ ranging from $1.24 \%$ for those fish fed clams to $3.85 \%$ for fish fed vegi-pro. Although we found that fractionation was $>1 \%$ for all diets, the results were consistent with previous studies that indicated that organisms fed plantbased diets typically fractionate $\delta^{13} \mathrm{C}$ by values $>2 \%$ (Benner et al. 1987, Howland et al. 2003). Plants contain complex biopolymers, including cellulose and lignin, that are poorly digested and often differ in $\delta^{13} \mathrm{C}$ relative to the bulk organic matter of the plant (e.g. Benner et al. 1987, Teece \& Fogel 2007). As a result, trophic fractionation of $\delta^{13} \mathrm{C}$ in herbivores is often higher than those of carnivores, with omnivores having intermediate fractionation (McCutchan et al. 2003). The commercial fish pellet bio-vita represented an omnivorous diet of animal matter (fish and krill meal) and plant matter (wheat gluten), and showed a $\delta^{13} \mathrm{C}$ fractionation that was intermediate between that of vegi-pro and the natural animal-based diets and similar to the value of several fish species fed commercial fish pellets (McCutchan et al. 2003).

Many researchers have estimated diets of fishes by assuming no significant trophic fractionation of carbon isotopes. Theoretically, if consumers incorporate carbon isotopes from their prey with minimal fractionation, then the consumer $\delta^{13} \mathrm{C}$ values will match that of its diet (Post 2002, Fry 2006). Our results suggest, however, that the assumption that $\delta^{13} \mathrm{C}$ values do not exhibit trophic fractionation may be unrealistic. The $<1 \%$ fractionation between prey and consumers has been derived largely from field studies (Fry 2006). Only a handful of papers have examined fractionation between diet and consumers in the laboratory under controlled conditions. The fractionation we detected was similar to data from previous laboratory studies $\left(\sim 3 \%\right.$ for $\delta^{13} \mathrm{C}$ ) (DeNiro \& Epstein 1978, Focken \& Becker 1998, Post 2002, Sweeting et al. 2007). We do not know the reason for the discrepancy between field and laboratory studies, but the observation is clearly repeatable and needs to be acknowledged by researchers using bulk $\delta^{13} \mathrm{C}$ analyses in food-web studies.

Fractionation of $\delta^{15} \mathrm{~N}$ from diet to fish muscle forms the basis by which tropic position can be established (Minagawa \& Wada 1984, Fry 2006). We found that $\delta^{15} \mathrm{~N}$ fractionation among the different dietary treatments ranged between 2.66 to $7.83 \%$. Similar to patterns with carbon, the largest fractionation in $\delta^{15} \mathrm{~N}$ values was detected for the artificial diet of vegi-pro $(7.83 \%)$ and the smallest fractionation for squid $(2.66 \%)$. Nitrogen isotope fractionation in bulk muscle tissue is approximately 3 to $4 \%$ among tropic levels (Fry 2006), but has been shown to range from 1.3 to $9 \%$ (Minagawa \& Wada 1984, Vander Zanden \& Rasmussen 2001, Goedkoop et al. 2006). If we exclude the vegi-pro diet, our results were in reasonable agreement with the consensus value. The diet treatments allowed for a useful test of the relative placement of groups with respect to trophic level enrichment. Conservative enrichment among diets should allow for fish to be distinguished based upon the trophic level at which they feed. Of the 5 diets, one had $\delta^{15} \mathrm{~N}$ values of $\sim 2 \%$ (vegi-pro), 3 were $\sim 11 \%$ (bio-vita, Artemia, clam), and one was $\sim 14 \%$ (squid). Therefore, diets were classified according to the trophic level of primary producers, secondary consumers, and tertiary consumers, respectively. Even with the extremely large fractionation seen in the vegi-pro treatment, fish from different dietary groups held their relative placements, such that fish feeding at different trophic levels were distinguishable from one another. 
Assumptions of $\delta^{15} \mathrm{~N}$ fractionation in food web studies appear relatively robust. However, the assumption that $\delta^{13} \mathrm{C}$ values do not fractionate between trophic levels appears to be more problematic. The increase in $\delta^{13} \mathrm{C}$ values between prey and consumer we detected of between 1.24 and $2.85 \%$ would cause an underestimation of ${ }^{13} \mathrm{C}$-depleted dietary sources and, conversely, an overestimation of ${ }^{13} \mathrm{C}$-enriched dietary sources. Gaye-Siessegger et al. (2004) calculated this underestimation using a mixing model of 2 food sources that differed by $3 \%$ in $\delta^{13} \mathrm{C}$. An error of $1 \%$ in $\delta^{13} \mathrm{C}$ values caused by one dietary component fractionating more than the other would cause the isotopically lighter diet to be underestimated by 17 to $83 \%$. More in-depth studies are warranted to investigate the biochemical and physiological underpinnings of these findings, specifically examining isotopic routing under varying diets and rearing times.

\section{Effects of lipid extraction}

Removing lipids from fish muscle before bulk SIA is generally performed to reduce bias caused by diet lipid content, growth, and metabolism (McConnaughey \& McRoy 1979, Sweeting et al. 2006, Post et al. 2007). Lipids are typically 6 to $8 \%$ lower in ${ }^{13} \mathrm{C}$ relative to carbohydrates and proteins (DeNiro \& Epstein 1977). We extracted lipids from fish muscle to determine if lipid content could affect $\delta^{13} \mathrm{C}$ values of mummichog as recommended by Post et al. (2007). We found that lipid extraction resulted in an increase in fish muscle $\delta^{13} \mathrm{C}$ values by approximately $1 \%$, consistent with previous studies on lipid removal from fish muscle (Pinnegar \& Polunin 1999, Sotiropoulos et al. 2004, Logan \& Lutcavage 2008). While lipid extraction impacted the $\delta^{13} \mathrm{C}$ value of fish muscle, the effects were not significantly different among treatments, and thus the general patterns of an increase in bulk tissue $\delta^{13} \mathrm{C}$ values remained consistent. Nonetheless, lipid extraction may be more critical when analysing more lipid-rich tissues (lipid content $>5 \%$ or $\mathrm{C}: \mathrm{N}$ ratio $>3.5$ for aquatic animals) or comparing consumers with significantly different lipid compositions (Post et al. 2007).

Lipid extraction caused an increase in $\delta^{15} \mathrm{~N}$ values that represented a change of approximately one-third of a trophic level, assuming standard trophic increase is $\sim 3 \%$. Although other studies have found similar results (Sotiropoulos et al. 2004, Sweeting et al. 2006, Logan \& Lutcavage 2008), the cause of this fractionation remains unknown. Most lipids do not contain nitrogen and therefore lipid extraction should have little, if any, effect on $\delta^{15} \mathrm{~N}$ values. Sotiropoulos et al. (2004) noted that at least some of the solvents used to extract lipids (i.e. methanol) are not lipid-specific. The process may also remove structural proteins and AAs that must presumably have lower $\delta^{15} \mathrm{~N}$ values than bulk protein. Although some have suggested using lipid normalization procedures to adjust data post hoc (Kiljunen et al. 2006, Sweeting et al. 2006), our results showing diet-specific fractionation suggest that using a standard normalization may not be valid. We second the recommendation of studies that have suggested samples be split into 2 aliquots, one analysed for $\delta^{13} \mathrm{C}$ values after lipid extraction and the other left untreated for measurement of $\delta^{15} \mathrm{~N}$ values (Sotiropoulos et al. 2004, Murry et al. 2006).

Lipid extraction also increased variation in $\delta^{15} \mathrm{~N}$ values, but not $\delta^{13} \mathrm{C}$ values. The increased variation associated with lipid-extracted samples is perhaps not surprising, because samples are being subjected to additional processing. Two studies have concluded that variance structure was not altered by lipid extraction (Sotiropoulos et al. 2004, Murry et al. 2006) based on tests for homogeneity of variances. We examined if lipid extraction increased sample variation by statistically comparing standard deviation between untreated and lipid-extracted samples (described by BenedettiCecchi 2003). Distortions in the relative position of treatment groups and added variability attributed to lipid removal did not, however, alter interpretations of differences among diet treatments based on statistical significance and components of variation.

\section{Fractionation from diet and muscle to otoliths and consistencies of trends}

We found strong positive correlations between diet and muscle $\delta^{13} \mathrm{C}$ values and otolith $\delta^{13} \mathrm{C}$ values. We also detected relatively consistent fractionation from diet to otolith and diet to muscle to otolith for all treatments, ranging from 12.1 to $14.5 \%$. Perhaps the most surprising result was the observation that differences in otolith $\delta^{13} \mathrm{C}$ values among treatments captured the entire range of diet $\delta^{13} \mathrm{C}$ values. This would seem to be only possible if carbon in otoliths is derived entirely from metabolic carbon, with DIC contributing only minimally. Unfortunately, we did not collect water samples to estimate $\delta^{13} \mathrm{C}$ values of DIC in our experiment. Nonetheless, we used a flow-through water system and therefore $\delta^{13} C_{\text {DIC }}$ values are likely to have been approximately $0 \%$ as determined by Kroopnick (1980) for nearshore Atlantic waters in Massachusetts. A simple mixing model (Kalish 1991) using a value of $0 \%$ for $\delta^{13} C_{\text {DIC }}$ and muscle tissue $\delta^{13} \mathrm{C}$ values to estimate metabolic $\delta^{13} \mathrm{C}$ suggested that metabolic carbon contributed $\sim 32 \%$ to total otolith carbon in our experiment from diet to otolith (range $=29.7$ to $36.9 \%$ for different diets). This contribution is obviously not easily 
reconciled with our observation that otolith $\delta^{13} \mathrm{C}$ values record the complete range of dietary $\delta^{13} \mathrm{C}$ values among treatments. One possible explanation is that diet treatments induced differences in metabolic activity that, in turn, generated differences in otolith $\delta^{13} \mathrm{C}$ among treatments. However, there was no significant differences in fish growth, and hence likely no differences in metabolic rate, among treatments. Several studies have suggested that respiratory or metabolic activity is positively correlated with intraspecific (Dufour et al. 2007) and interspecific (Sherwood \& Rose 2003) variability in otolith $\delta^{13} \mathrm{C}$ values. Our data may, therefore, be a function of variation in metabolic activity, from relatively low values in the plant diet to highest values in fish fed squid diet. Whatever the explanation, researchers should be careful when applying general mixing models to estimate the contributions of metabolic carbon and DIC to otoliths.

The ability to reconstruct diet information from otolith $\delta^{13} \mathrm{C}$ values would represent a significant advance in food-web studies involving fish. Unlike analyses of isotopes in soft tissues, otoliths are metabolically inert and therefore may reveal prey preferences of individual fish from different life-history periods. Currently, this level of information can only be obtained by sampling fish at different life-history periods and tracing cohorts of fish through time. Otolith analyses would, therefore, have distinct advantages over analyses of soft tissue, saving both time and money. However, we believe that it is premature to suggest, based on our results, that otolith $\delta^{13} \mathrm{C}$ values reflects $\delta^{13} \mathrm{C}$ values of prey, despite the strong correlation we detected between otolith and diet $\delta^{13} \mathrm{C}$ values. We are equally cautious in suggesting that otolith $\delta^{13} \mathrm{C}$ values can be used to calculate fish movements based on patterns of ambient DIC, irrespective of diet changes (Solomon et al. 2006). This conclusion was based on diet having negligible effect on otolith $\delta^{13} \mathrm{C}$, which is not supported by our data or earlier research (Radtke et al. 1996). There is little doubt that otolith $\delta^{13} \mathrm{C}$ values contain lifetime information on carbon sources of individual fish. Further studies will, however, be required to determine the degree to which researchers can distinguish among changes in diet, DIC, and metabolic rate based solely on $\delta^{13} \mathrm{C}$ measurements in otoliths.

Acknowledgements. We thank D. Champlin, J. Serbst, and B. Miner for spawning Fundulus, assisting with tank setup, feeding, and providing general support during the rearing period. L. Houghton helped with sample preparation. Constructive comments and advice were provided by R. McKinney, B. Murry, R. Pruell, and B. Taplin. This research was funded by the Ocean Life Institute at Woods Hole Oceanographic Institution (sample analysis), and the Atlantic Ecology Division of the U.S. Environmental Protection Agency. T.S.E. received support from the Postdoctoral Scholar program at the Woods
Hole Oceanographic Institution, with funding provided by the Ocean Life Institute, and an ARC fellowship at University of Adelaide. K.W.M. received support from a National Science Foundation Graduate Research Fellowship. The contribution number of this manuscript is AED-09-025. Although the research presented in this paper has been wholly funded by the US Environmental Protection Agency, it has not been subjected to Agency level review. Therefore, it does not necessarily reflect the views of the Agency. Mention of trade names or commercial products does not constitute endorsement or recommendation for use.

\section{LITERATURE CITED}

Anderson MJ (2001) A new method for non-parametric multivariate analysis of variance. Austral Ecol 26:32-46

> Bearhop S, Teece MA, Waldron S, Furness RW (2000) Influence of lipid and uric acid on $\delta^{13} \mathrm{C}$ and $\delta^{15} \mathrm{~N}$ values of avian blood: implications for trophic studies. Auk 117:504-507

> Benedetti-Cecchi L (2003) The importance of the variance around the mean effect size of ecological processes. Ecology 84:2335-2346

Benner R, Fogel ML, Sprague EK, Hodson RE (1987) Depletion of ${ }^{13} \mathrm{C}$ in lignin and its implications for stable carbon isotope studies. Nature 329:708-710

Campana SE (1999) Chemistry and composition of fish otoliths: pathways, mechanisms and applications. Mar Ecol Prog Ser 188:263-297

Chisholm BS, Nelson DE, Schwarcz HP (1982) Stable-carbon isotope ratios as a measure of marine versus terrestrial protein in ancient diets. Science 216:1131-1132

Collette BB, Klein-MacPhee G (2002) Bigelow and Schroeder's fishes of the Gulf of Maine. Smithsonian Institution, Washington, DC

> DeNiro MJ, Epstein S (1977) A mechanism of carbon isotope fractionation associated with lipid synthesis. Science 197: 261-263

> DeNiro MJ, Epstein S (1978) Influence of diet on the distribution of carbon isotopes in animals. Geochim Cosmochim Acta 42:495-506

Dufour E, Gerdeaux D, Wurster CM (2007) Whitefish (Coregonus lavaretus) respiration rate governs intra-otolith variation of $\delta^{13} \mathrm{C}$ values in Lake Annecy. Can J Fish Aquat Sci 64:1736-1746

Estrada JA, Lutcavage M, Thorrold SR (2005) Diet and trophic position of Atlantic bluefin tuna (Thunnus thynnus) inferred from stable carbon and nitrogen isotope analysis. Mar Biol 147:37-45

> Focken U, Becker K (1998) Metabolic fractionation of stable carbon isotopes: implications of different proximate compositions for studies of the aquatic food webs using $\delta^{13} \mathrm{C}$ data. Oecologia 115:337-343

Fry B (2006) Stable isotope ecology. Springer, New York

Fry B, Sherr EB (1984) $\delta^{13} \mathrm{C}$ measurements as indicators of carbon flow in marine and freshwater ecosystems. Contrib Mar Sci 27:13-47

Gannon JE (1976) The effects of differential digestion rates of zooplankton by alewife, Alosa pseudoharengus, on determination of selective feeding. Trans Am Fish Soc 105: 89-95

Gaye-Siessegger J, Focken U, Muetzel S, Abel H, Becker K (2004) Feeding level and individual metabolic rate affect $\delta^{13} \mathrm{C}$ and $\delta^{15} \mathrm{~N}$ values in carp: implications for food web studies. Oecologia 138:175-183

> Goedkoop W, Åkerblom N, Demandt MH (2006) Trophic fractionation of carbon and nitrogen stable isotopes in Chiro- 
nomus riparius reared on food of aquatic and terrestrial origin. Freshw Biol 51:878-886

Graham MH, Edwards MS (2001) Statistical significance versus fit: estimating the importance of individual factors in ecological analysis of variance. Oikos 93:505-513

Haas HL, Freeman CJ, Logan JM, Deegan L, Gaines EF (2009) Examining mummichog growth and movement: Are some individuals making intra-seasonal migrations to optimize growth? J Exp Mar Biol Ecol 369:8-16

Hansson S, Hobbie JE, Elmgren R, Larsson U, Fry B, Johansson $S$ (1997) The stable nitrogen isotope ratio as a marker of food-web interactions and fish migration. Ecology 78 : 2249-2257

- Herzka SZ, Holt GJ (2000) Changes in isotopic composition of red drum (Sciaenops ocellatus) larvae in response to dietary shifts: potential applications to settlement studies. Can J Fish Aquat Sci 57:137-147

Hobson KA, Wassenaar LI (1999) Stable isotope ecology: an introduction. Oecologia 120:312-313

> Høie H, Folkvord A, Otterlei E (2003) Effects of somatic and otolith growth rate on stable isotopic composition of early juvenile cod (Gadus morhua L.) otoliths. J Exp Mar Biol Ecol 289:41-58

Howland MR, Corr LT, Young SM, Jones V and others (2003) Expression of the dietary isotope signal in the compoundspecific $\delta^{13} \mathrm{C}$ values of pig bone lipids and amino acids. Int J Osteoarchaeol 13:54-65

Kalish JM (1991) Oxygen and carbon stable isotopes in the otoliths of wild and laboratory-reared Australian salmon (Arripis trutta). Mar Biol 110:37-47

Kiljunen M, Grey J, Sinisalo T, Harrod C, Immonen H, Jones RI (2006) A revised model for lipid-normalization $\delta^{13} \mathrm{C}$ values from aquatic organisms, with implications for isotope mixing models. J Appl Ecol 43:1213-1222

Kroopnick P (1980) The distribution of ${ }^{13} \mathrm{C}$ in the Atlantic Ocean. Earth Planet Sci Lett 49:469-484

> Logan JM, Lutcavage ME (2008) A comparison of carbon and nitrogen stable isotope ratios of fish tissues following lipid extractions with non-polar and traditional chloroform/ methanol solvent systems. Rapid Commun Mass Spectrom 22:1081-1086

Mann RK, Orr DR (1969) A preliminary study of the feeding relationships of fish in a hard-water and a soft-water stream in southern England. J Fish Biol 1:31-44

McArdle BH, Anderson MJ (2001) Fitting multivariate models to community data: a comment on distance-based redundancy analysis. Ecology 82:290-297

> McConnaughey T, McRoy CP (1979) Food-web structure and the fractionation of carbon isotopes in the Bering Sea. Mar Biol 53:257-262

McCutchan JHJ, Lewis WMJ, Kendall C, McGrath CC (2003) Variation in trophic shift for stable isotope ratios of carbon, nitrogen, and sulfur. Oikos 102:378-390

Melville AJ, Connolly RM (2003) Spatial analysis of stable isotope data to determine primary sources of nutrition for fish. Oecologia 136:499-507

- Minagawa M, Wada E (1984) Stepwise enrichment of ${ }^{15} \mathrm{~N}$ along food chains: further evidence and the relation between $\delta^{15} \mathrm{~N}$ and animal age. Geochim Cosmochim Acta 48:1135-1140

Murry BA, Farrell JM, Teece MA, Smyntek PM (2006) Effect of lipid extraction on the interpretation of fish community

Editorial responsibility: Stylianos Somarakis,

Heraklion, Greece trophic relationships determined by stable carbon and nitrogen isotopes. Can J Fish Aquat Sci 63:2167-2172

Newsome SD, del Rino CM, Bearhop S, Phillips DL (2007) A niche for isotope ecology. Front Ecol Environ 5:429-436

> Ostermann DR, Curry WB (2000) Calibration of stable isotope data: an enriched $\delta^{18} \mathrm{O}$ standard used for source gas mixing detection and correction. Paleoceanography 15: $353-360$

> Parkington J (1991) Approaches to dietary reconstructions in the Western Cape: Are you what you have eaten? J Archaeol Sci 18:331-342

> Pinnegar JK, Polunin NVC (1999) Differential fractionation of $\delta^{13} \mathrm{C}$ and $\delta^{15} \mathrm{~N}$ among fish tissue: implications for the study of trophic interactions. Funct Ecol 13:225-231

Post DM (2002) Using stable isotopes to estimate trophic position: models, methods, and assumptions. Ecology 83: 703-718

Post DM, Layman CA, Arrington DA, Takimoto G, Quattrochi J, Montaña CG (2007) Getting to the fat of the matter: models, methods and assumptions for dealing with lipids in stable isotope analyses. Oecologia 152:179-189

Radtke RL, Showers W, Moksness E, Lenz P (1996) Environmental information stored in otoliths: insights from stable isotopes. Mar Biol 127:161-170

Schlechtriem C, Focken U, Becker K (2004) Stable isotopes as a tool for nutrient assimilation studies in larval fish feeding on live food. Aquat Ecol 38:93-100

Schwarcz HP (1991) Some theoretical aspects of isotopic paleodiet studies. J Archaeol Sci 18:261-275

- Sherwood GD, Rose GA (2003) Influence of swimming form on otolith $\delta^{13} \mathrm{C}$ in marine fish. Mar Ecol Prog Ser 258: 283-289

Solomon CT, Weber PK, Cech JJJ, Ingram BL and others (2006) Experimental determination of the sources of otolith carbon and associated isotopic fractionation. Can J Fish Aquat Sci 63:79-89

Sotiropoulos MA, Tonn WM, Wassenaar LI (2004) Effects of lipid extraction on stable carbon and nitrogen isotope analyses of fish tissues: potential consequences for food web studies. Ecol Freshw Fish 13:155-160

> Sweeting CJ, Polunin NVC, Jennings S (2006) Effects of chemical lipid extraction and arithmetic lipid correction on stable isotope ratios of fish tissue. Rapid Commun Mass Spectrom 20:595-601

> Sweeting CJ, Barry JT, Polunin NVC, Jennings S (2007) Effects of body size and environment on diet-tissue $\delta^{13} \mathrm{C}$ fractionation in fishes. J Exp Mar Biol Ecol 352:165-176

> Teece MA, Fogel ML (2007) Stable carbon isotope biogeochemistry of monosaccharides in aquatic organisms and terrestrial plants. Org Geochem 38:458-473

Vander Zanden MJ, Rasmussen JB (2001) Variation in $\delta^{15} \mathrm{~N}$ and $\delta^{13} \mathrm{C}$ trophic fractionation: implications for aquatic food web studies. Limnol Oceanogr 46:2061-2066

Vanderklift MA, Ponsard S (2003) Sources of variation in consumer-diet $\delta^{15} \mathrm{~N}$ enrichment: a meta-analysis. Oecologia 136:169-182

Vaughan GM, Corballis MC (1969) Beyond tests of significance: estimating strength of effects in selected ANOVA designs. Psychol Bull 72:204-213

Wurster CM, Patterson WP (2003) Metabolic rate of late Holocene freshwater fish: evidence from $\delta^{13} \mathrm{C}$ values of otoliths. Paleobiology 29:492-505

Submitted: September 4, 2009; Accepted: January 26 Proofs received from author(s): May 17, 2010 